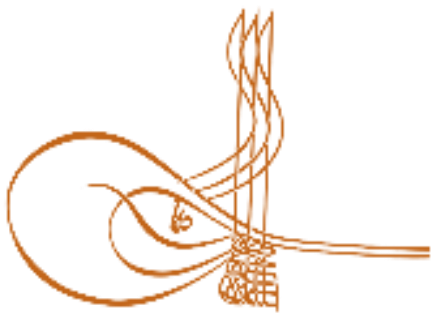

www.turkishstudies.net/social
Turkish Studies - Social Sciences

eISSN: $2667-5617$

Research Article / Araștırma Makalesi

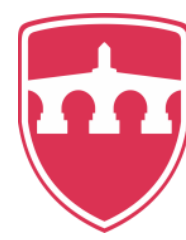

INTERNATIONAL

BALKAN

UNIVERSITY

Sponsored by IBU

\title{
Okul Öncesi Eğitime Devam Eden Beş Yaşındaki Çocukların Korkularının Çizdikleri Resimlerine ve Sözel Anlatımlarına Göre İncelenmesi ${ }^{*}$
}

\author{
Investigation of the Fear of the Five Year-Old Children Continuing the Pre-School Education \\ According to the Pictures and Verbal Expressions
}

\author{
Mehmet Ayhan $^{* *}$ - Mehmet Nur Tuğluk ${ }^{* * *}$
}

\begin{abstract}
One of the benefits of preschool education. Fear is part of human life, but the origin of some obsessive fears is attributed to childhood. It can be said that the situations that cause childhood obsessions and fears over time. The aim of this study is to examine the fears of five drivers who continue preschool education according to their illustrated and verbal expressions. Changes here were asked to answer the questions "What are the fears of five-sight pre-school reviews? Is there a significant relationship between their fears and their gender?"The study was made with phenomenology (phenomenology) pattern. The data of the study were collected from Istanbul, Van, Diyarbakır, Ağrı and Batman provinces in the fall semester of the 2019-2020 academic year. The study group consists of 34 girls and 33 boys from six different preschool classes. The data of the study consist of pictures drawn by children and interviews with children. The findings of the research were analyzed with the content analysis method. Accordingly, nine different themes have been created. The most emphasized theme is the animal theme. Apart from the animal theme, respectively; Themes of mass media, physical violence, sudden noises, natural disaster, darkness, police and thieves have emerged. In some themes, there are some differences between the genders of children, but in general, similar fears have been observed. As a result of the research, it was determined that there was fear in all children and the reasons for this were discussed. Some suggestions were made at the end of the research.
\end{abstract}

Structured Abstract: This study addresses children's fears with the technique of drawing and interviewing. Painting for the child is a means of thinking and in this way reflects his thoughts. The technique of drawing can be more meaningful than many words in order to understand the child's inner world.

The aim of this study is to examine the fears of 5-year-old children who continue their preschool education according to their pictures and verbal expressions. The reason why only 5 age groups (60-69) are preferred in the

\footnotetext{
* Çalışmadaki veriler 2019 yılında toplanmıştır.

** Eğitim uzmanı, Yıldız Teknik Üniversitesi, Eğitim Fakültesi, Temel Eğitim Bölümü, Okul Öncesi Öğretmenliği Education Specialist, Yıldı Technical University, Faculty of Education, Elementary Education, Early Childhood Education ORCID 0000-0002-0835-1820

mhmtyhn0@gmail.com

*** Dr. Öğr. Üyesi, Yıldız Teknik Üniversitesi, Eğitim Fakültesi, Temel Eğitim Bölümü, Okul Öncesi Öğretmenliği Asst. Prof. Dr., Ylldız Technical University, Faculty of Education, Elementary Education, Early Childhood Education ORCID 0000-0003-2007-5942

mntugluk@yildiz.edu.tr
}

Cite as/ Atıf: Ayhan, M., Tuğluk, M.N., (2020). Okul öncesi eğitime devam eden beş yaşındaki çocukların korkularının çizdikleri resimlerine ve sözel anlatımlarına göre incelenmesi, Turkish Studies - Social, 15(3), 937-952. https://dx.doi.org/10.29228/TurkishStudies.41761

Received/Geliş: 13 February/Şubat 2020

Accepted/Kabul: 25 April/Nisan 2020

Checked by plagiarism software

Copyright $(C)$ INTAC LTD, Turkey

Published/Yayın: 30 April/Nisan 2020

CC BY-NC 4.0 
study is that this age group expresses themselves better through pictures and interviews. In this care, answers to the following questions are sought: What are the fears of 5-year-old children in preschool? Is there a significant relationship between the fears of 5-year-old preschool children and their gender?

When we examine the literature, we encounter some studies on children's fears: mental states in parents of children with school fear (Özcan ve diğerleri, 2006); concerns of sick children and their families (Gültekin ve Baran, 2005); effects of divorce on children (Türkarslan, 2007); The impact on television and children (Büyükbaykal, 2007); death theme in children's books (Aytekin, 2008); problems faced by parents with children in kindergarten (Inan, 2010), elements of fear in story books for preschool children (Öztürk ve Giren, 2016) etc. many publications are available.

This study was done with phenomenology (phenomenology) pattern. The phenomenon that is tried to be explained is the fears of preschool children. The data of the study are among 67 children $(34$ girls $(n=34)$ and 33 boys $(n=33)$ who are 5 years old who continue their education in Istanbul, Van, Diyarbakır, Ağrı and Batman provinces in the fall semester of 2019-2020 academic year. $(n=67)$ was obtained. In the study, maximum diversity sampling, which is a sub-technique of the purposeful sampling method, is used in the selection of samples. The data of the research constitute sound recordings based on pictures and interviews drawn by children. Pictures, which are one of the data of the research, were obtained with the draw and tell technique. In order to strengthen the research, a total of 10 children, 5 girls and 5 boys, were interviewed. During this meeting, the children were asked two open-ended questions. After asking the children two questions in the interview, the answers were transmitted by the researcher to the article. These questions are: What are you afraid of? Why are you afraid of (fear)? The data in this research were analyzed by content analysis method. In the study, the researcher examined the pictures one by one and focused on their meanings and made qualifications. As a result of the qualifications, certain themes emerged. The researcher grouped these emerging themes under a specific title. Later, themes were compiled separately for girls and boys. Interview records, another data collection method in the study, were deciphered and transcribed by the researcher. Each interview was examined one by one and themed with specific qualifications. When creating themes, the meaning of sentences is concentrated. Then, the themes formed as a result of interviews and pictures were compared and analyzed. In order to ensure reliability, the data were analyzed at different times and a $98.5 \%$ consistency was found between the codings performed.

The order of the themes that occur is based on the frequency of preference: $45.33 \%(n=34)$ of children say that they are afraid of animals, $26.66 \%(n=20)$ of these children are girls and $18.66 \%(n=14)$ it is male. While $26.66 \%(n=20)$ children are afraid of the situations caused by mass media, $16 \%(n=12)$ of these children are girls and $10.66 \%(\mathrm{n}=8)$ are boys. While $8 \%(\mathrm{n}=6)$ children say they are afraid of physical violence, $5.33 \%$ $(n=4)$ of these children are girls and $2.66 \%(n=2)$ are boys. While $6.66 \%(n=5)$ children are afraid of sudden noises, $4 \%(n=3)$ of these children are girls and $2.66 \%(n=2)$ are boys. While $5.33 \%(n=4)$ children say they are afraid of natural disasters, $2.66 \%(\mathrm{n}=2)$ of these children are girls and $2.66 \%(\mathrm{n}=2)$ are boys. While $4 \%(\mathrm{n}=$ 3 ) children say they are afraid of the dark, $1.33 \%(n=1)$ of these children are girls and $2.66 \%(n=2)$ are boys. While $1.33 \%(\mathrm{n}=1)$ children say they are afraid of the police, all of these children are $1.33 \%(\mathrm{n}=1)$ girls. While $1.33 \%(n=1)$ children are afraid of thieves, all of these children are $1.33 \%(n=1)$ men. While $1.33 \%(n=1)$ children say they are not afraid of anything, all of these children are $1.33 \%(n=1)$ men.

While the majority of children say that they are afraid of the dog, only one child said that he was afraid of elephant and one child was afraid of giraffe. It can be said that learning from a close distance is also effective on the fears while the children say their fears. It is seen that children living in rural areas are afraid of animals such as bears, wolves and snakes. Even if children do not encounter such animals directly, it can be said that the environmental factor seriously affects such a fear. The fears of people who are close to the child may have affected the fears of the child. In the same way, it can be said that family members can develop fear in the same situation in the event of fear (a child mentioned the mother who was afraid of the mouse). Similarly, the child can create fears against animals with printed or non-printed media organs, especially through the media. Girls emphasized animal fears and went into more detail and emphasized more animal species. Boys expressed animal fears, while girls emphasized 5 animal species and girls emphasized 12 animal species. The culture of fear caused by media elements in children has remained alive until today. While creating media contents, it can produce such a result either deliberately or deliberately. The reason for this is that the media is so common and indispensable, that these creators have limited or incorrect information about child development and psychology. It has been observed that mass communication means cause fear in both rural children and urban children. In addition to the fact that no 
significant difference was observed in the fear caused by mass media between girls and boys, girls were not found to be monster qualifiers, while four of them were monsters.

When the fears of the children were examined, similar results were obtained with the previous studies. Although it is often said that fear is gained later, the certainty of this situation is not clear. While the children expressed their fears, no significant difference was found between their general and gender. While some situations caused by fear are unknown, some situations are predicted to feed fear. Accordingly, the following recommendations are presented:

- $\quad$ Parents can improve themselves on their child's development and psychology.

- $\quad$ Educators can prevent serious problems that may arise by following the children well in and out of school and seeking help from stakeholders in abnormal situations.

- $\quad$ Media organs can prevent serious problems by better monitoring the content created or not for children.

Keywords: Educational science, Preschool, Child, Fear, Five years

Öz: Okul öncesi eğitiminin kazanımlarından birisi çocukların kendi duygu durum özelliklerinin bilincinde olmasıdır. Korku insan yaşamının bir parçası olmakla birlikte bazı saplantılı korkuların kökeni çocukluk dönemine atfedilmektedir. Çocukluk döneminde meydana gelen bazı durumların saplantılara ve zamanla korkulara yol açtığ söylenebilir. Bu çalışmanın amacı, okul öncesi eğitime devam eden beş yaşındaki çocukların korkularının çizdikleri resimlerine ve sözel anlatımlarına göre incelenmesidir. Bu amaçla çalışmada "Okul öncesi dönemdeki beş yaşındaki çocukların korkuları nelerdir? Korkularıyla cinsiyetleri arasında anlamlı bir ilişki var mıdır?" sorularına cevap aranmıştır. Çalışma fenomoloji (olgu bilimi) deseniyle yapılmıştır. Çalışmanın verileri 2019-2020 eğitim ve öğretim yılı güz döneminde İstanbul, Van, Diyarbakır, Ağrı ve Batman illerinden toplanmıştır. Çalışma grubu altı farklı okul öncesi sınıfından 34 kız çocuğu ve 33 erkek çocuğundan oluşmaktadır. Çalışmanın verilerini çocukların çizdiği resimler ve çocuklarla yapılan görüşmeler oluşturmaktadır. Araştırmanın bulguları içerik analizi yöntemiyle çözümlenmiştir. Bu doğrultuda dokuz farklı tema oluşmuştur. En fazla vurgulanan tema hayvan temasıdır. Hayvan temasının dışında sırasıyla; kitle iletişim araçları, fiziksel şiddet, ani gürültüler, doğal afet, karanlık, polis ve hırsız temaları ortaya çıkmıştır. Bazı temalarda çocukların cinsiyetleri arasında anlamlı bir farka rastlansa da genel olarak benzeşik korkuların daha baskın olduğu görülmüştür. Araştırmanın sonucunda çocukların hepsinde bir korku olduğu belirlenmiş ve bunun sebepleri tartışılmıştır. Araştırmanın sonunda bazı önerilerde bulunulmuştur.

Anahtar Kelimeler: Eğitim bilimleri, Okul öncesi, Çocuk, Korku, Beş yaş

\section{Giriş}

Okul öncesi eğitimi; zorunlu eğitim yaşını doldurmamış çocukların, okul öncesi eğitim kurumlarının yapılandırılmış ortamlarında bilişsel, fiziksel ve sosyal-duygusal yönden gelişimlerini desteklemek amacıyla verilen eğitimi kapsamaktadır (MEB, 2013). Başka bir tanıma göre; çocuğun doğduğu andan zorunlu eğitim yaşına gelinceye kadar olan ve gelişimini birçok alanda destekleyen çok yönlü eğitim programıdır (Düşek ve Dönmez, 2012). Okul öncesi eğitimi, çocukların tüm gelişim alanlarını destekleyen, ailesiyle ve çevresiyle olumlu ilişkiler geliştirmesi bakımından kritik bir öneme sahiptir (Arabacı ve Aksoy, 2005). Bu bakımdan okul öncesi eğitimi çocuklara sosyal ve duygusal gelişimlerine yönelik birçok beceri kazandırmalıdır. Bu kazanımlardan biri de çocukların öz benlik algılarının farkında olma bilincidir (Senemoğlu, 1994). Yani çocuklardan kendi duygu durum özelliklerinin; mutlu veya mutsuz olduğu durumları, korktuğu veya korkmadığı durumların farkında olma bilincine sahip olması beklenmektedir.

Korku: "Bir tehlike veya tehlike düşüncesi karşısında duyulan kaygı, üzüntü”, "Gerçek veya beklenen bir tehlike ile yoğun bir acı karşısında uyanan coşku, beniz sararması, ağız kuruması, kalp atışı hızlanması vb. belirtileri olan veya daha karmaşık fizyolojik değişmelerle kendini gösteren duygu." olarak karşımıza çıkmaktadır (TDK, 2019). Korku durumunun fiziksel, duygusal ve sosyal açıdan birçok 
sebebi bulunabilir (Sargın, 2012). NEILL (2000)'e göre korkunun temel sebebi ölümden kaçmaktır. Yani korku fantazilerinin tetikleyicisi ölüm korkusudur denilebilir. Yetişkinliğe karşın çocukluk döneminde korkuların ve fobilerin oluşmasında çok daha fazla etmen baş gösterebilir. Birçok korkunun ve fobinin kökenini çocukluk dönemine atfetmemiz yanlış olmaz. Bundaki gerekçe; çocuğun dünyayı anlamlandırmasındaki eksiklikleri ve buna bağlı geliştirdiği yanlış yönelimleri olduğunu söyleyebiliriz. Piaget ve Inhelder (2019)' e göre bu korku durumu denge ve dengesizlik durumundan, Freud (2013)'a göre ise bilinçaltı çatışma durumundan kaynaklanmaktadır. Çocuklardaki belli başlı korku ve kaygı türlerine bakacak olursak; hayvan korkusu, obje korkusu, duygusal eksiklik(sevilme,güven) korkusu, karanlık ve gürültü korkusu, hayali korkular, hastalık korkusu, okul korkusu vb. bir çok korku türü karşımıza çıkmaktadır (Yavuzer, 2015). Bu korkuların bazıları zaman içerisinde kaybolurken bazıları ise zaman içerisinde şiddetini artırmaktadır. Bazı korkular diğer korkuları tetikleyip besleyebilmektedir. Dockett ve Perry (2016)' e göre okul korkusu, çocukta oluşmuş ve kaybolmuş diğer korkuları şiddetlendirebilmektedir.

Literatürü incelediğimizde çocukların korkularıyla ilgili yapılan bazı çalışmalar karşımıza çıkmaktadır: okul korkusu olan çocukların ebeveynlerinde görülen ruhsal durumlar (Özcan ve diğerleri, 2006); hasta çocukların ve ailelerinin endişeleri (Gültekin ve Baran , 2005); boşanmanın çocuklar üzerindeki etkileri (Türkarslan, 2007); televizyon ve televizyonun çocuklar üzerindeki etkisi (Büyükbaykal, 2007); çocuk kitaplarındaki ölüm teması (Aytekin, 2008); anaokulunda çocukları olan ebeveynlerin karşılaştığı problemler (İnan, 2010), okul öncesi dönemi çocuklarına yönelik hikaye kitaplarındaki korku unsurları (Öztürk ve Giren, 2016) vb. birçok yayına ulaşılabilir.

$\mathrm{Bu}$ çalışma, çocukların korkularını resim çizme ve görüşme tekniğiyle ele alacağı için bu tekniklerinde incelenmesinde fayda vardır. Belirli bir fiziksel olgunluğa erişen her çocuk bazı karalamalar gerçekleştirir. Çocukların yaptığı karalamalar her ne kadar birbirine benzese de her çocuğun çizimi adete parmak izi gibi tektir. Çocuklar yaptığı resimlerle bize sadece bir çizim örneği sunmamakta aynı zamanda bilişsel, sosyal ve duygusal açıdan birçok detayını yansıtmaktadır. Çocuk için resim bir düşünme aracıdır ve bu yolla düşüncelerini yansıtmaktadır (Yavuzer, 2017). Çocukların resimlerine bakarak ihtiyaçlarını, duygularını anlayabiliriz (Savaş, 2014). E. Pignon (1966; akt. Yavuzer, 2015, s.194)' a göre resim var olan karekterin şimdiki halini yansıtan bir öğenin yanında aynı zamanda geçmişteki duyguların da bir yansımasıdır. Resim çocuğun kendini anlatmasındaki en güçlü araçlardan biridir (Yavuzer, 2015). Susan Back (Akt. Çankırılı, 2008, s.78)' e göre çocuklar, içerisinde yaşadığ1 dünyanın karmaşıklığını, öfkelerini ve korkularını resimleriyle anlatmaktadır. Çocuğun iç dünyasını anlayabilmek için resim çizme tekniği birçok sözcükten daha anlamlı olabilir (Yavuzer, 2017).

Çocuklarla yapılan resim çalışmalarını incelediğimizde: çocukların iç dünyalarının resim yoluyla incelenmesi (Bat1, 2012); çocukların okula ilişkin algıları (Aksoy ve Baran , 2010); öğretmen figürünün incelenmesi (Dağlığlu, 2011); çocukların hastaneye yatma etkilerinin resimlerine yansıması (Beytut, ve diğerleri , 2009); kötü, iyi kavramlarının resimler yoluyla incelenmesi (Yüksel ve diğerleri , 2015); çocukların değer algıları (Sapsağlam, 2017); okul öncesindeki çocukların oyuncak algıları (Karaman ve Akyol, 2011); empati duygusunun çocuk resimleriyle incelenmesi (Gönen ve Özer, 2011); çocukların spor algılarının resimler yoluyla incelenmesi (Yüksekusta ve Şahin, 2016) vb. birçok çalışmaya ulaşılabilir.

$\mathrm{Bu}$ çalışmanın amacı, okul öncesi eğitime devam eden beş yaşındaki çocukların korkularının çizdikleri resimlerine ve sözel anlatımlarına göre incelenmesidir. Çalışmada sadece beş yaş grubunun (60-69) tercih edilmesindeki sebep, bu yaş grubunun kendilerini resim ve görüşme yoluyla daha iyi ifade ettiklerinden dolayıdır (Sapsağlam, 2017). Bu bakımdan şu sorulara cevap aranmaktadır:

1. Okul öncesi dönemdeki 5 yaş çocukların korkuları nelerdir?

2. Okul öncesi dönemdeki 5 yaş çocukların korkularıyla cinsiyetleri arasında anlamlı bir ilişki var mıdır?

Turkish Studies - Social, 15(3) 
Literatür incelendiğinde okul öncesindeki çocukların korkuları üzerinde sınırlı sayıda araştırmaya ulaşılmıştır. Bu çalışma korku temalı bir araştırmada, resim analizi ve görüşme tekniğiyle veri toplamasından dolayı özgündür. Yapılan bu çalışma çocukların korkularını doğrudan gözlemleme firsatı sağlayıp, psikolojik ve pedagojik çalışmalara katkı sağlayacağı düşünüldüğünden dolayı önem taşımaktadır.

\section{Yöntem}

\section{Araştırmanın Deseni}

$\mathrm{Bu}$ çalışma, amacına ve sorularına yanıt bulmak adına fenomoloji (olgu bilimi) deseniyle yapılmıştır. Fenomenolojik araştırma, bir araştırmada araştırmacının, fenomenin kaynağıyla bire bir vakit geçirip deneyimlerini betimlenmesidir (Creswell, 2017). Husserl (2012. Akt. Seggie ve Bayyurt, 2017, s.70) öğrencilerden konunun asıl sahipleriyle, yani olaydan etkilenen ile görüşülmesinin olayların özüne açılılık getirdiğini savunur. Heidegger (1964, Aktaran: Ilgaz, 2018)'e göre, "Fenomen, kendini göstermeyen, geride duran "olan" açıklanmaya çalışılan fenomen, okul öncesi dönemde olan beş yaşındaki çocukların korkularıdır.

\section{Çalışma Grubu}

Çalışmanın verileri 2019-2020 eğitim ve öğretim yılı güz döneminde İstanbul, Van, Diyarbakır, Ağrı ve Batman illerinde eğitimine devam eden 5 yaşındaki 34'ü kız, 33'ü erkek olmak üzere toplam 67 çocuktan elde edilmiştir. Çalışmada örneklem seçiminde seçkisiz olmayan örnekleme yöntemlerinden, amaçsal örnekleme yönteminin bir alt tekniği olan maksimum çeşitlilik örnekleme kullanılmıştır. Maksimum örnekleme, temel problemle alakalı durumların kendi içerisinde benzer ve farklı yönlerini keşfetmek açısından temaları çeşitlendiren veya bütünleştiren bir örneklemdir (Grix, 2010; akt. Baltacı, 2018). Nitel çalışmalar gibi örneklemlerin sınırlı tutulduğu çalışmalarda daha fazla bilgi elde edilmesini sağlar (Travers, 2001; akt. Baltacı, 2018). Çalışma grubundaki okulların demografik özellikleri şöyledir; bir şehir merkezine uzak köy anaokulu (Diyarbakır), bir merkezi köy anaokulu (Batman), üç orta düzey gelir dağılımı gösteren şehir merkezinde bulunan anaokulu (İstanbul, Van, Ağrı) ve bir yüksek gelir dağılımı gösteren şehir merkezinde bulunan anaokulu (Van) seçilmiştir. Çalışma grubunda yer alan çocukların tamamı normal gelişim gösteren ve özel gereksinimi bulunmayan çocuklardan oluşmaktadır.

\section{Verilerin Toplanması}

Araştırmadaki veriler toplanmadan, UNICEF desteğiyle oluşturulmuş ERIC (Çocuklarla İlgili ve Çocuklarla Birlikte Yapılan Araştırmalarda Gözetilecek Etik Kurallar) e-kitabı (Graham ve diğerleri, 2013) araştırmacı tarafından gözden geçirilmiş ve araştırma bu titizlikte yapılmıştır.

Araştırma verileri, çocukların çizdiği resimler ve çocuklarla yapılan görüşmelere dayalı ses kayıtlarından oluşmaktadır. Araştırmanın verilerinden biri olan resimler, çiz ve anlat tekniği ile elde edilmiştir. Araştırma yapılmadan önce, çocuklarla birlikte bir ön hazırlık yapılmamıştır. Araştırmacı gerekli izinleri aldıktan sonra, okul idaresiyle görüşmüş ve ardından çalışmayı yapacağı sınıfta çocuklarla zaman geçirmiştir. Sonrasında eğitim akışını bozmadan sırayla çocuklardan resim yapmalarını istemiştir. Araştırmacı sınıf içerisinde uygun bir köşeye geçmiş ve çocukları tek tek yanına çağırıp resim yapmalarını istemiştir. Çocukların tek tek çağırılmasının nedeni birbirlerinin yaptığı resimlerden etkilenmemelerini sağlamaktır. Araştırmacı masaya pastel boya, kuru boya ve a-4 kâğıdı koymuştur. Çocukların renk ve boya seçimine müdahale edilmemiştir. Araştırmacı yanına gelen çocuğa "Nelerden korkuyorsan onu çizmeni istiyorum" dedikten sonra çocuk resim çizerken araştırmacı uygun pozisyonda (çocuğa çok yakın veya çok uzak olmadan) durarak notlar almıştır. Resmini bitiren çocuktan resminde ne çizdiğini anlatması istenmiştir ve anlatılanlar resmin önüne ve arkasına not alınmıştır. 
Araştırmayı güçlendirmek amacıyla 5 kız ve 5 erkek olmak üzere toplamda 10 çocukla görüşme yapılmıştır. Yapilan bu görüşmelerde çocuklara açık uçlu iki soru sorulmuştur. Görüşmelerde aşağıdaki sorular sorulduktan sonra, cevaplar araştırmacı tarafından yazıya aktarılmıştır.

Soru 1: Sen nelerden korkarsin?

Soru 2: Neden (korkundan) korkarsin?

\section{Verilerin Analizi}

Veri analizi araştırmaların geçerliliği adına en önemli basamaktır. Özellikle nitel araştırmalarda çalışmanın kaderi, veri analizine bağlıdır. Bu bakıma nitel araştırma yapan kişiler veri analiz sürecinde oldukça dikkatli olmalıdırlar. Veri analizi araştırmada istatistiksel veya niteliksel sonuca varmak adına yapılan veri çözümleme sürecidir. (Büyüköztürk, 2018). Bu araştırmadaki veriler içerik analizi yöntemi ile çözümlenmiştir.

İçerik analizi nitel çalışmalarda sıklıkla tercih edilen bir yöntemdir. İçerik analizinde kullanılacak veriler yazılı olmasının yanında görsel verilerden de oluşabilir (Silverman, 2001; akt. Özdemir, 2010). İçerik analizi bir veri kümesinin içerisinde bulunan verilerden, kelimelerin veya söylemlerin anlamlarına yoğunlaşarak kodlamalar veya gruplamalar yoluyla tümevarımsal bir sonuca ulaşma yöntemidir (Büyüköztürk ve diğerleri, 2018).

Yapılan çalışmada araştırmacı resimleri tek tek inceleyip anlamlarına yoğunlaşarak nitelemeler yapmıştır. Bazı resimler konu kapsamı dışında tutulup ayıklanmıştır. Nitelemeler neticesinde belirli temalar meydana gelmiştir. Araştırmacı meydana gelen bu temaları belirli bir başlık altında gruplamıştır. Daha sonra temalar kız ve erkek çocukları için ayrı ayrı derlenmiştir.

Araştırmada bir diğer veri toplama yöntemi olan görüşme kayıtları araştırmacı tarafından deşifre edilip yazıya aktarılmıştır. Her görüşme tek tek incelenip belirli nitelemelerle temalaştırılmıştır. Temalar oluşturulurken cümlelerin anlamına yoğunlaşılmıştır. Ardından görüşmeler ve resimler sonucunda oluşan temalar birbirleriyle karşılaştırılarak çözümlenmiştir.

Her araştırmada olduğu gibi nitel araştırmalarda da güvenirlik oldukça önemlidir. İçerik analizi yapılan bir çalışmanın güvenirliliğini bulmak adına iki yöntem geliştirilmiştir. Birincisi araştırma verileri başka araştırmacı tarafından da çözümlenip her iki tema karşılaştırılır. İkinci yöntem ise araştırmacı farklı zamanlarda verileri çözümleyip bunları birbiriyle karşılaştırır (Seggie ve Bayyurt, 2017). Bu çalışmada ikinci yöntem olan farlı zamanlardaki çözümlemeler birbirleriyle karşılaştırılmıştır. Güvenirliğin istatistiksel sonucuna varmak adına Miles-Huberman tarafından geliştirilen aşağıdaki formül kullanılmıştır:

$$
\text { Güvenirlik = Uzlaşma sayısı / (Uzlaşma + Uzlaşmama Sayısı) }
$$

Yapılan kodlamalar arasında \%98,5 oranında bir tutarlılık saptanmıştır.

\section{Bulgular}

Tablo 1: Toplanan Tüm Verilerin Genel Dağılımı

\begin{tabular}{lllc}
\hline \multicolumn{3}{c}{$\operatorname{Resim}(\mathrm{N} / \%)$} & Görüşme (N/\%) \\
\hline \multicolumn{2}{l}{ Toplam(N/\%) } & & \\
\hline Kadın & $28 / 41.79$ & $5 / 7.46$ & $33 / 49.25$ \\
Erkek & $29 / 43.28$ & $5 / 7.46$ & $34 / 50.75$ \\
\hline Toplam & $57 / 85.07$ & $10 / 14.03$ & $67 / 100$ \\
\hline
\end{tabular}


Tablo 1'de yer alan bilgilere bakıldığında resim verileri $57(\% 85,07)$ çocuktan toplanmışken, görüşme verileri ise $10(\% 14,03)$ çocuktan toplanmıştır. Toplamda $67(\% 100)$ çocuk ile resim ve görüşme yapılmıştır. Resim çalışmasına katılan çocukların 28 'i $(\% 41,79)$ erkek ve 29 'u $(\% 43,28)$ kız iken görüşme yapılan çocukların 5'i $(\% 7,46)$ erkek ve 5'i $(\% 7,46)$ kızdır. Çalışmaya toplamda 34 $(\% 50,75)$ kız katılmışken, $33(\% 49,25)$ erkek katılmıştır. Çalışmaya toplamda $32(\% 50,75)$ erkek ve 31 (49.25) kız çocuğu katılmıştır.

Tablo 2 bu çalışmanın amacını teşkil eden çocuk korkularının toplanan veriler neticesinde içerik analizi sonucu ortaya çıkan ana temaları göstermektedir. Ana temalar çocukların korkularının kaynağından yani korkulara sebep olan durumların nedenleri sonucunda ortaya çıkmıştır. Temalar cinsiyetlere göre ayrı ayrı kodlanmış ve toplam sonuç tabloda gösterilmiştir. Bu verilere sadece resim çalı̧̧ması sonucunda ulaşılmıştır.

Tablo 2: Korkulara Sebep Olan Durumlardan Oluşan Temalar

\begin{tabular}{lccc}
\hline No.Tema & Kadın(N/\%) & Erkek(N/\%) & Toplam(N/\%) \\
\hline $\begin{array}{c}\text { 1.Hayvan } \\
\text { 2.Kitle }\end{array}$ & $20 / 26.66$ & $14 / 18.66$ & $34 / 45.33$ \\
$\begin{array}{c}\text { iletişim } \\
\text { araçları }\end{array}$ & $12 / 16$ & $8 / 10.66$ & $20 / 26.66$ \\
$\begin{array}{c}\text { 3.Fiziksel } \\
\text { şiddet }\end{array}$ & $4 / 5.33$ & & \\
4. Ani & & $2 / 2.66$ & $6 / 8$ \\
gürültüler & $3 / 4$ & & \\
5. Doğal & & $2 / 2.66$ & $5 / 6.66$ \\
afet & $2 / 2.66$ & $2 / 2.66$ & $4 / 5.33$ \\
6.Karanlık & $1 / 1.33$ & $2 / 2.66$ & $3 / 4$ \\
7.Polis & $1 / 1.33$ & $0 / 0$ & $1 / 1.33$ \\
8.Hırsız & $0 / 0$ & $1 / 1.33$ & $1 / 1.33$ \\
9.Hiçbir & & $1 / 1.33$ & $1 / 1.33$ \\
șey & $0 / 0$ & $43 / 54.66$ & $75 / 100$ \\
\hline Toplam & $43 / 54.66$ & &
\end{tabular}

Tablo 2 incelendiğinde çocukların çizdiği resimlerin temalarının cinsiyete göre dağılımında toplamda 9 tema oluşmuştur. Ortaya çıkan temaların sıralaması tercih edilme sıklı̆̆ına göre düzenlenmiştir ve bunun neticesinde şu bulgulara ulaşılmıştır: \%45,33 ( $\mathrm{n}=34)$ çocuk, hayvanlardan korktuğunu söylerken, bu çocuklardan \%26,66'sı(n=20) k1z ve \%18,66's1 (n=14) erkektir. \%26,66 $(n=20)$ oranında çocuk, kitle iletişim araçlarının sebep olduğu durumlardan korkarken, bu çocuklardan $\% 16$ 's1 (n=12) k1z ve \%10,66'ü $(n=8)$ erkektir. \%8 (n=6) çocuk, fiziksel şiddetten korktuğunu söylerken, bu çocuklardan \%5.33'ü $(n=4)$ kız ve \%2,66'sı $(n=2)$ erkektir. \%6,66 $(n=5)$ çocuk, ani gürülttülerden korktuğunu söylerken, bu çocuklardan \%4'ü $(n=3)$ kız ve \%2,66's1 $(n=2)$ erkektir. \%5.33 (n=4) çocuk, doğal afetlerden korktuğunu söylerken, bu çocuklardan \%2,66's1 $(n=2)$ kız ve \%2,66's1 $(n=2)$ erkektir. \%4 $(\mathrm{n}=3)$ çocuk, karanlıktan korktuğunu söylerken, bu çocuklardan \%1.33'ü $(\mathrm{n}=1)$ k1z ve \%2,66's1 $(\mathrm{n}=2)$ erkektir. \%1.33 $(\mathrm{n}=1)$ çocuk, polisten korktuğunu söylerken, bu çocukların tamamı $\% 1.33$ 'ü $(\mathrm{n}=1)$ kızdır. \%1.33’ü ( $\mathrm{n}=1)$ çocuk, hırsızdan korktuğunu söylerken, bu çocukların tamamı \%1.33'ü $(\mathrm{n}=1)$ erkektir. \%1.33 (n=1) çocuk, hiçbir şeyden korkmadığını söylerken, bu çocukların tamamı \%1.33’ü $(n=1)$ erkektir.

Araştırmanın veri kaynaklarından biri olan resim çalışmalarının temalandırılış̧ bazı örnekleri aşağıda sunulmuştur. 


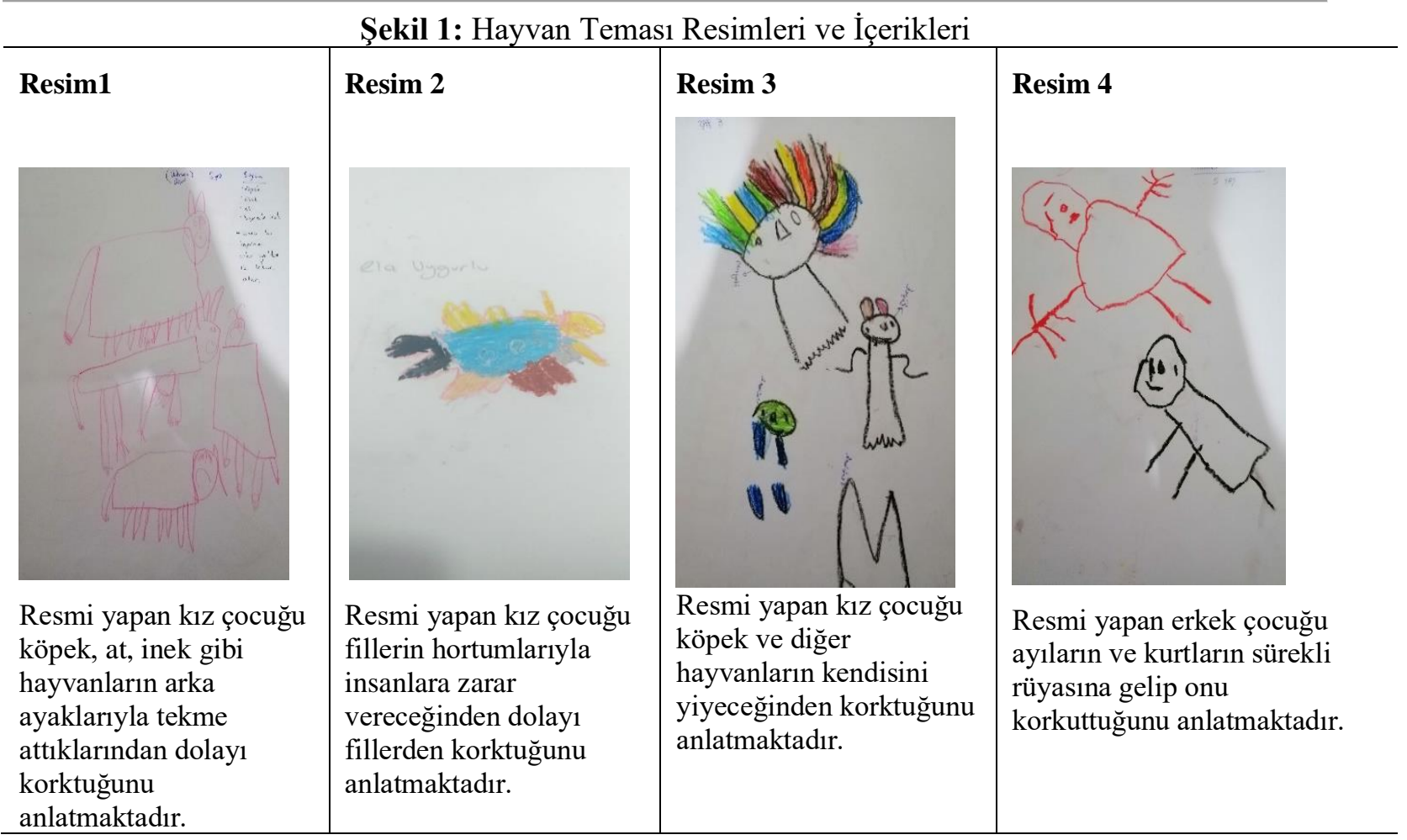

Şekil 1 incelendiğinde çocukların hayvanlardan korktuğu resimler görülmektedir. Çocukların köpek, at ve inek(resim1) gibi hayvanlardan korktuğu, fillerden(resim2) korktuğu, ayılardan ve kurtlardan korktuğu görülmektedir. Çocuklar çizdiği resimlerinde bu hayvanların dışında sıklıkla yılanlar, böcekler, fareler gibi hayvanlardan nadiren ise kirpi, zürafa, arı, balık gibi hayvanlardan korktuklarını belirtmişlerdir.

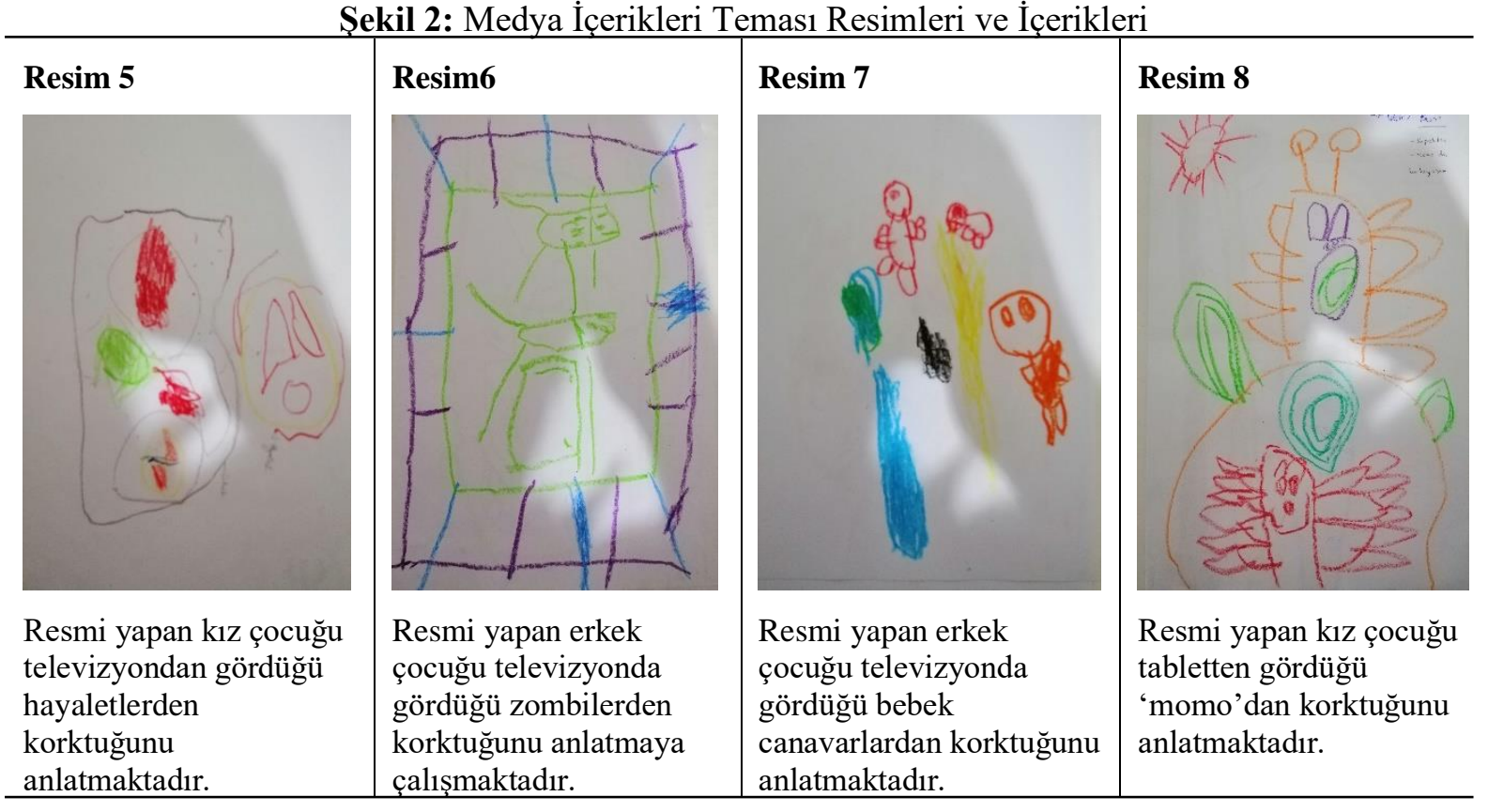


Şekil 2 incelendiğinde çocukların medya içeriklerinden kaynaklanan bazı öğelerden korktuğu görülmektedir. Çocuklar daha çok televizyon içeriklerinden kaynaklanan hayalet (resim 5), zombi (resim 6), canavar (resim 7) korktuklarının yanında tablet gibi video içeriği oluşturulmuş momo adlı korkutucu bir öğeden korktukları görülmektedir. Çocukların çizdiği resimlerde sıklıkla canavar, hayalet, zombi gibi korkutucu öğelere değinirken, nadiren de cad1, momo, gibi öğelere değindikleri görülmektedir.

Şekil 3: Fiziksel Șiddet Teması Resimleri ve İçerikleri

\begin{tabular}{l|l|l|l|}
\hline Resim9 & Resim 10 & Resim 11 \\
\hline $\begin{array}{l}\text { Resmi yapan erkek } \\
\text { çocuğu kendinden } \\
\text { büyük bir adamdan } \\
\text { dayak yediği için } \\
\text { korktuğunu } \\
\text { anlatmaktadır. }\end{array}$ & $\begin{array}{l}\text { Resmi yapan erkek } \\
\text { çocuğu arkadaşlarılya } \\
\text { top oynarken kafasına } \\
\text { çarpmasından } \\
\text { korktuğunu } \\
\text { anlatmaktadır. }\end{array}$ & $\begin{array}{l}\text { Resmi yapan erkek } \\
\text { çocuğu oyun oynarken } \\
\text { arkadaşından korktuğunu } \\
\text { anlatmaktadır. }\end{array}$ & $\begin{array}{l}\text { Resmi yapan kız çocuğu } \\
\text { kötü insanlardan } \\
\text { korktuğunu } \\
\text { anlatmaktadır. }\end{array}$ \\
\hline
\end{tabular}

Şekil 3 incelendiğinde çocukların kendinden yaşça büyük birinden dayak yemekten korktuğu (resim 9), oyun esnasında oyun materyalinden (resim 10) ve oyun arkadaşlarından (resim 11) korktuğu ve bazı kötü insanların kendilerine zarar verebileceğinden korktukları görülmektedir. Çocukların çizdiği resimlerde oyun esnasında veya normal günlük rutin içerinde kendilerine zarar verebilecek bazı kişilerden korktukları görülmektedir. 


\begin{tabular}{|c|c|c|c|}
\hline \multicolumn{4}{|c|}{ Șekil 4: Ani Gürültü Teması Resimleri ve İçerikleri } \\
\hline Resim13 & Resim14 & Resim15 & Resim16 \\
\hline $46=0$ & 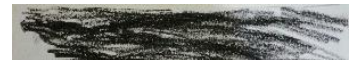 & & \\
\hline $3 i_{0,0}$ & & & \\
\hline $\begin{array}{l}\text { Resmi yapan erkek } \\
\text { çocuğu yağmur yağınca } \\
\text { korktuğunu } \\
\text { anlatmaktadır. }\end{array}$ & $\begin{array}{l}\text { Resmi yapan erkek } \\
\text { çocuğu şimş̧ek çakınca } \\
\text { çok korktuğunu } \\
\text { anlatmaktadır. }\end{array}$ & $\begin{array}{l}\text { Resmi yapan erkek } \\
\text { çocuğu tost makinasından } \\
\text { çıkan sesten korktuğunu } \\
\text { anlatmaktadır. }\end{array}$ & $\begin{array}{l}\text { Resmi yapan kız çocuğu } \\
\text { patlamış mısırın çıkardığ } 1 \\
\text { sesten korktuğunu } \\
\text { anlatmaktadır.. }\end{array}$ \\
\hline
\end{tabular}

Şekil 4 incelendiğinde çocukların gök gürültüsü ve şimşek gibi ani ve şiddetli seslerden korktukları (resim 13, 14), tost makinası gibi bir ev aletinden çıan sesten korktukları(resim15) ve patlayan mısır gibi bir yiyeceğin yapıldığı esnada çıkardığı sesten korktukları(resim16) görülmektedir. Çocukların cisim veya madde fark etmeksizin her türlü öğeden çıkan şiddetli veya ani seslerden korktukları görülmektedir.

Şekil 5: Doğal Afet, Polis, Karanlık, Hırsız Teması Resimleri ve İçerikleri

\begin{tabular}{l|l|l|l|}
\hline Resim17 & Resim18 & Resim19 \\
\hline $\begin{array}{l}\text { Resmi yapan erkek } \\
\text { çocuğu kayaların evlerine } \\
\text { ve üstün düşmesinden } \\
\text { korktuğunu } \\
\text { anlatmaktadır. }\end{array}$ & $\begin{array}{l}\text { Resmi yapan kız } \\
\text { çocuğu polisin } \\
\text { kendisini alıp } \\
\text { götüreceğinden } \\
\text { korktuğunu } \\
\text { anlatmaktadır. }\end{array}$ & $\begin{array}{l}\text { Resmi yapan erkek } \\
\text { çocuğu karanlıktan } \\
\text { korktuğunu evlerinin hep } \\
\text { aydınlık olmasını } \\
\text { istediğini anlatmaktadır. }\end{array}$ & $\begin{array}{l}\text { Resmi yapan erkek } \\
\text { çocuğu evlerine giren } \\
\text { hirsıdan çok korktuğunu } \\
\text { anlatmaktadır. }\end{array}$ \\
\hline
\end{tabular}


Şekil 5 incelendiğinde çocukların doğal afetten korktukları(resim17), polisten korktuklar1(resim18), karanlıktan korktuklar1(resim19) ve hırsizdan korktuklar1(resim20) görülmektedir.

Bu öğelerin yanında çocuklardan bir tanesi hiç korkmadığını ve bu yüzden normal bir manzara resmi çizdiğini söylemiştir.

Araştırmanın diğer veri kaynağını oluşturan görüşmeler tablo şeklinde sunulmuştur.

Tablo 3: Çocuklarla Yapılan Görüşme Soruları Ve Sorulara Verilen Cevaplar

\begin{tabular}{|c|c|c|}
\hline K1 & Bizim eve giderken & $\begin{array}{c}\text { Top kafamı } \\
\text { kanatır }\end{array}$ \\
\hline $\mathrm{K} 2$ & $\begin{array}{c}\text { katama top çarpmıştı. } \\
\text { Kartallardan } \\
\text { korkarım }\end{array}$ & $\begin{array}{l}\text { Kanatur } \\
\text { Kartallar } \\
\text { çocukları } \\
\text { yer }\end{array}$ \\
\hline K3 & Bebeklerden & $\begin{array}{l}\text { Onlar çok } \\
\text { ağlarlar }\end{array}$ \\
\hline K4 & $\begin{array}{l}\text { Kaybolursam annem } \\
\text { beni bulamaz }\end{array}$ & ----- \\
\hline K5 & Polis & $\begin{array}{l}\text { Beni alır } \\
\text { götürür. }\end{array}$ \\
\hline E1 & Gece karanlık olursa & $\begin{array}{c}\text { Yaşlı } \\
\text { adamların } \\
\text { dişleri var }\end{array}$ \\
\hline E2 & $\begin{array}{l}\text { Abim momodan } \\
\text { korkar }\end{array}$ & ----- \\
\hline E3 & $\begin{array}{c}\text { Benim arkadaşım } \\
\text { ablamın kafasını } \\
\text { kırdı. Ben de } \\
\text { korkmuştum }\end{array}$ & $\begin{array}{l}\text { Kafam } \\
\text { kanarsa } \\
\text { ölürüm }\end{array}$ \\
\hline E4 & $\begin{array}{c}\text { Canavarlar } \\
\text { televizyondan çıkarsa } \\
\text { korkarım }\end{array}$ & ----- \\
\hline E5 & $\begin{array}{l}\text { Örümcekler yuva } \\
\text { yapınca bizi Isırırlar }\end{array}$ & ---- \\
\hline
\end{tabular}

Tablo 3' te katılımcılar K (kız çocuğu) ve E (erkek çocuğu) olarak kodlanmıştır. Tablo incelendiğinde iki çocuğun hayvanlardan korktuğu (K2, E5), iki çocuğun medya içerikli öğelerden korktuğu (E2, E4), iki çocuğun fiziksel şiddet görmekten korktuğu (K1, E3), bir çocuğun kaybolmaktan korktuğu(K4), bir çocuğun bebeklerden korktuğu(K3), bir çocuğun polisten korktuğu(K5) ve bir çocuğunda karanlıktan korktuğu(E1) görülmektedir. Çocuklardan altı tanesi her iki soruyu da yanıtlarken, üç kız (E2, E4, E5) ve bir erkek(K4) ikinci soruyu yanıtlamamışlardır.

\section{Tartışma ve Sonuç}

$\mathrm{Bu}$ araştırmanın amacı okul öncesi eğitimine devam eden 5 yaşındaki (60-69 Ay) çocukların korkularının incelenmesidir. Araştırmanın neticesinde 9 ana tema oluşmuştur.

Çalışma sonucunda en çok tercih edilen tema hayvan teması olmuştur. Hayvan temasını tercih etmiş çocukların çoğu birebir deneyim sonucunda bu korkuyu oluşturmuştur. Çocuklardan bazılarını köpek kovalamış bazılarının da evlerine yılan, fare girmiştir. Fakat bazı çocuklar bu korkuları bire bir deneyimlemeseler de zihinlerinde oturtmuşlardır. Bu çocuklar filler, zürafalar ile hiç karşılaşmamalarına rağmen korktuklarını söylemişlerdir. Oğuz (2019)'un okul öncesi çocuklarla yaptığ 1 görüşmelerde çocukların en çok hayvan korkusu olduğu saptanmıştır. Aynı şekilde Öveç (2012) tarafindan yapılan yüksek lisans tezinde çocuklar korkularını vurgularken her yaş çocuğun hayvan temasını sıklıkla 
vurguladığı görülmektedir. Çocukların büyük çoğunluğu köpekten korktuğunu söylerken sadece bir çocuk fil, bir çocuk da zürafadan korktuğunu söylemiştir. Çocuklar korkularını söylerken yakından uzağa öğrenmenin korkular üzerinde de etkili olduğu söylenilebilir. Çocukların daha kırsal kesimlerde yaşayanların ayı, kurt, yılan gibi hayvanlardan korktuğu görülmektedir. Çocuklar bu gibi hayvanlarla direkt olarak karşılaşmasalar bile böyle bir korkunun oluşmasında çevre faktörünün ciddi şekilde etki ettiği söylenilebilir. Çocuğa yakın olan kişilerin korkuları çocuğun korkularını etkilemiş olabilir. Aynı şekilde aile bireylerinin korku anında çocuğunda aynı duruma korku geliştirebileceği(bir çocuk fareden korkan annesinden sözetmiştir) söylenebilir. Yine aynı aynı şekilde çocuk basılı veya basılı olmayan yayın organlarıyla özellikle medya unsuru aracılığıyla hayvanlara karşı korkular oluşturabilir. Kız çocukları hayvan korkularını vurgularken daha fazla ayrıntıya girerek daha çok hayvan çeşidine vurgu yapmışlardır. Erkek çocuklar ise hayvan korkularını belirtirken 5 hayvan türüne kız çocukları ise 12 hayvan türüne vurgu yapmışlardır.

Çalışma sonucunda ikinci sıklıkla tercih edilen medya içeriklerinin sebep olduğu öğelerdir. Bu öğeler içerisinde zombi, canavar, cadı, hayalet gibi korku unsurları yer almaktadır. Çocuklar bu korkuları resmettiğinde veya söylediklerinde sıklıkla televizyon, tablet veya bilgisayar gibi medya yayın organlarına atıfta bulunmuşlardır. Çocuklarda oluşan böyle korkularda medya okuryazarlı̆̆ının zayıf olması ve medya yayın organlarının dikkatsiz bir şekilde yayın oluşturmaları olduğu söylenebilir. Bunun yanında bazı çocuklar ailelerinin batıl inançlarından dolayı böyle bir korku unsurunu oluşturabilir veya şiddetlendirebilir. Medya unsunlarının çocuklarda sebep olduğu korku kültürü ortaya çıktıktan günümüze kadar diriliğini korumuştur. Medya içerikleri oluşturulurken gerek kasten gerek kasten olmayarak böyle bir sonuç doğurabilir. Bunun nedeni medyanın bu kadar yaygın ve vazgeçilmez olmasının yanında bu içerik oluşturucuların çocuk gelişimi ve psikolojisi hakkında kısıtlı veya yanlış bilgilere sahip olduğu söylenebilir. Yapılan birçok araştırmada (Büyükbaykal, 2007; Öztürk 2006; Tahiroğlu ve diğerleri, 2010; Ünal ve Durualp, 2012; Scheer ve diğerleri, 2019) medyanın çocuklarlar üzerinde ciddi derecede korkuya sebep olduğu gözlenmiştir. Araştırmaya katılan çocuklar arasında bölgesel olarak bir fark gözlenmemiştir. Kırsal kesimde yaşayan çocuklarda da şehirde yaşayan çocuklarda da kitle iletişim araçlarının korkuya sebep olduğu gözlenmiştir. Kız çocukları ve erkek çocuklarını arasında kitle iletişim araçlarının sebep olduğu korkuda anlamlı bir far gözlemlenmemesinin yanında kız çocukları canavar nitelemesinde hiç bulunmazken erkek çocuklarından dört tanesi canavar nitelemesinde bulunmuştur.

Çocukların üçüncü sıklıkta tercih ettiği tema fiziksel şiddettir. Çocuklar bu temayı vurgularken insanların kendisine zarar verebileceğine, fiziksel olarak (dayak, kasten bir şeyler firlatma, akran zorbalığı) incitilebileceğine değinmiştir. Çocukların içinde bulundukları bazı olumsuz durumlar çocuğa doğrudan fiziksel bir zarara neden olabilir. $\mathrm{Bu}$ durum gerek ailede gerek okulda meydana gelebilmektedir. Pedagojik açıdan yetersiz bireyler çocuğun sorunlarını fiziksel şiddet ile bastırma eğilimine gidebilirler. Böyle bir korkunun oluşması çocukta fiziksel zarar oluşturmasının yanında duygusal birç̧ok probleme de neden olabilir. Fiziksel şiddet gören çocuklar kendisinde oluşmamış veya oluşmuş birçok duygu durum bozukluklarını şiddetlendirebilir. Öveç (2012)' nin de belirttiği gibi fiziksel şiddet çocuktaki olumsuz problemleri ciddi derece de arttırabilir. Çocuklardan hiçbiri doğrudan ailesinden zarar gördüğünü söylemezken, akran zorbalığına maruz kaldıklarını belirtmişlerdir. Okuldaki bazı durumlar doğrudan gözlenebilirken bazı durumlarda dolaylı olarak çocuğa yansımaktadır. Akran zorbalığına maruz kalan çocuklar okula gitmemek için tüm dirençlerini gösterirler. Akran zorbalığı sadece okulda değil aynı zamanda okul dışı oyun alanlarında da ortaya çıkabilir. Böyle durumlarda çocuğun kendini ailesine ifade etmesi, rahat bir şekilde anlatabilmesi ileride oluşacak birçok ciddi problemi beraberinde getirir. Eğer bir çocuk okula başladığı yıllarda akran zorbalığına maruz kalırsa bu ileriki yıllarda da çocuğun okula karşı olumsuz tutumunu katılaştırır. Bunların dışında çocuklar bu temaya vurgu yaparken cinsiyetler arasında anlamlı bir farka rastlanmamıştır.

Çocukların dördüncü sıklıkta tercih ettiği ani gürültülerdir. Çocuklar bu temaya vurgu yaparken resimlerinde gök gürültüsü, tost makinası, patlayan mısır gibi dış seslerden etkilendiklerini 
resmetmişlerdir. İnsanlar doğdukları anda veya zamanla bazı refleksler elde ederler. Bu reflekslerden biride irkilme rekleksidir. Fakat bu fefleks zamanla kaybolur. Yani ani gürültüden korkma irkilme refleksi ile karıştırılmamalıdır. Öveç (2012) ve Oğuz (2019) un yaptığı çalışamada da ani seslerden korma temasına rastlanmaktadır. Bu tür korkular DSM 5'te anksiyeti bozuklukları başlığı altında sınırlandırılan özgül fobiler kategorisindedir. Özgül fobilerin nedeni tam olarak bilinmemektedir. Bu durumun nedenlerine bakıldığında tvavmatik vakaların yanında kalıtımsal olduğuda görülmüsstür (Uyan ve diğerleri, 2018). Çocuklar bu temaya vurgu yaparken cinsiyetleri arasında anlamlı bir farka ratlanmamıştır.

Çocuklar bu temalar dışında doğal afet, karanlık, polis, hırsız gibi temalara da vurgu yapmışlardır. Ssadece bir erkek çocuğu hiçbir şeyden kormadığını söylemiştir. Doğal afete vurgu yapan çocuklar dağlık bölgede yaşayan çocuklardır. Bu korkunun nedenini sorduğumuzda cevap alamadık fakat böyle korkuların oluşmasında yaşanmış travmatik vakalar ve çocukların yanında anlatılan afetsel olayların etkili olduğu söylenilebilir. Ve yaşanmış başka bir tavmatik vaka, korku bu korkuyu besleyebilir. Mesela yükseklik korkusu olan birinin normal cadde de yürürken üzerine birşeyler düşecekmiş gibi bir korku tasarlayabilir. Çocukların korktuğu bir diğer tema karanlıktır. İnan (2010)'ın ailelerle yaptığı çalışmada aileler çocuklarda böyle bir korkunun olduğunu söylemişlerdir. Böyle bir korkunun oluşmasında birçok etmen boy gösterebilir. Epsikiyatri (2010)'e göre karanlık korkusu sonradan oluşan bir korkudur. Bu korkunun oluşmasında ailelerin çocukları büyük bir yaşa kadar yanlarında uyutmaları ve çocukların yanında anlatılan tuhaf hikayeler olduğu söylenebilir. Çocukların cinsiyetleri arasında karanlık korkusunda anlamlı bir farka rastlanmamıştır. Kız çocuklarından bir tanesi polisten korktuğunu ve kendisini alıp götüreceğini nitelemiştir. Bunun temel nedeni ailelerin çocukları cazalandırırken kullandığı hatalı söylemler olabilir. Erkek çocuklardan bir tanesi de hırsızdan korktuğunu ve bunun nedenini de evlerine giren hırsız olduğunu belirtmiştir. Çocukla yapılan görüşme incelendiğinde ortaya çıkan temalarda yapılan resim çalışmasının temaları ile neredeyse birebir benzerlik gösterdiği söylenebilir. Bazı temaların oluşmamasında görüşmenin sadece 10 çocukla yapıldığından kaynaklandığı söylenebilir.

Çocukların korkuları incelendiğinde daha önceden yapılmış çalışmalarla benzeşik sonuçlar ortaya çıkmıştır. Korkunun sonradan kazanıldığı sıklıkla söylense de bu durum kesin değildir. Çocuklar korkularını belirtirken genel itibari ile cinsiyetleri arasında ciddi bir farka rastlanmamıştır. Korkunun neden olduğu bazı durumlar bilinmezken bazı durumların korkuyu beslediği öngürülmektedir. $\mathrm{Bu}$ doğrultuda şu öneriler sunulmaktadır:

1. Aileler çocuklarının gelişimi ve psikolojisi hakkında kendilerini geliştirebilirler.

2. Eğitimciler okul içinde ve okul dışında çocukları iyi takip ederek ve anormal durumlarda paydaşlardan yardım isteyip oluşabilecek ciddi problemlerin önüne geçebilirler.

3. Yayın organları çocuklar için olsun veya olmasın oluşturulan içerikleri daha iyi takip ederek ve önlemler alarak problemlerin önüne geçebilirler.

4. Çocuklar için oluşturulan basılı veya görsel öğeler için çocuk psikologları ile işbirliği içerisinde olabilirler.

\section{Kaynakça}

Aksoy, P., ve Baran , G. (2010). 60-72 aylık çocukların okula ilişkin algılarının resim yoluyla incelenmesi. International Conference on New Trends in Education and Their Implications, ,(s. 283-296).

Arabac1, N., ve Aksoy, A. B. (2005). Okul öncesi eğitime katılım programının annelerin bilgi düzeylerine etkisi. Hacettepe Üniversitesi Eğitim Bilimleri Dergisi, 29, 18-26. https://doi.org/10.1501/egifak_0000001333 
Aytekin, H. (2008). Çocuk edebiyatında ölüm teması. Selçuk Üniversitesi Sosyal Bilimler Enstitüsü Dergisi(20), 89-102.

Baltacı, A. (2018). Nitel araştırmalarda örnekleme yöntemleri ve örnek hacmi sorunsalı üzerine kavramsal bir inceleme. Bitlis Eren Üniversitesi Sosyal Bilimler Enstitüsü Dergisi, 7(1), 231274. https://doi.org/10.30803/adusobed.411797

Bat1, D. (2012). 4-12 yaş: Çocuk resimleri ve onların iç dünyalarının resimlerine yansıması. Yüksek Lisans Tezi. http://hdl.handle.net/20.500.12397/7129

Beytut, Ş. D., Bolışık, B., Solak, U., ve Seyfioğlu, U. (2009). Çocuklarda hastaneye yatma etkilerinin projektif yöntem olan resim çizme yoluyla incelenmesi. Maltepe Üniversitesi Hemşirelik Bilim Ve Sanat Dergisi, 2(3), 35-44.

Büyükbaykal, G. (2007). Televizyonun çocuklar üzerindeki etkileri. İstanbul Üniversitesi İletişim Fakültesi Dergisi, 0(28).

Büyüköztürk, Ş. (2018). Sosyal bilimler için veri analizi el kitabı (24. bask1). Pegem Akademi. https://doi.org/10.14527/9789756802748

Büyüköztürk, Ş., Çakmak, E. K., Akgün, Ö. E., Karadeniz, Ş., ve Demirel, F. (2018). Eğitimde bilimsel araştırma yöntemleri (25. baskı). Pegem Akademi. https://doi.org/10.14527/9789944919289

Creswell, J. W. (2017). Araştırma Deseni- nitel, nicel ve karma yöntem yaklaşımları (3. baskı). (S. B. Demir, Çev.) Eğiten Kitap.

Çankırıl1, A. (2008). Çocuk resimlerinin dili. Zafer Yayınları.

Dağlığlu, H. E. (2011). 5-7 yaş grubu çocukların resimlerine yansiyan öğretmen figürünün karşılaştırmalı olarak incelenmesi. Eğitim ve bilim dergisi, 36(160), 144-155.

Dockett, S., ve Perry, B. (2016). Okula geçiş (1. baskı). (N. S. Erkan, Çev.) Nobel Akademik Yayıncılık.

Düşek, G., ve Dönmez, B. (2012). Türkiyede yayımlanan okul öncesi eğitim programları. Mesleki Bilimler Dergisi, 1(1), 68-75.

Epsikiyatri. (2010, 12 6). Karanlı korkusu. 12 4, 2019 tarihinde epsikiyatri nöroepsikiyatri portalı: https://www.e-psikiyatri.com/KARANLIK-KORKUSU

Freud, S. (2013). Çocukta fobinin analizi (2. Bask1). (D. Muradoğlu, Çev.). Say Yayınevi.

Gönen, M., ve Özer, G. (2011). Okul öncesi eğitim kurumlarına devam eden çocukların yaptıkları resimlerde oyuncak çizimlerinin incelenmesi. Uluslararası Erken Çocukluk Ĕgitimi Araştırmaları Dergisi, 1(1), 56-72. https://doi.org/10.37754/664852.2020.513

Graham, A., Powell, M., Taylor, N., Anderson, D. \& Fitzgerald, R. (2013). Ethical Research Involving Children. Florence: UNICEF Office of Research - Innocenti.

Gültekin, G., ve Baran, G. (2005). Hastalık ve çocuk. Aile ve Toplum Dergisi, 2(9).

Ilgaz, T. (2018). Varlık ve Hiçlik. Çevirmenin Birkaç Notu. (9. Baskı). İthaki Yayınları

İnan, H. Z. (2010). Anaokulu çağı çocukları olan anne-babaların karşılaştıkları problemler. Milli Eğitim Dergisi, O(188), 218-229.

Karaman, Y., ve Akyol, A. K. (2011). Okul öncesi eğitim kurumlarına devam eden çocukların yaptıkları resimlerde oyuncak çizimlerinin incelenmesi. Çukurova Üniversitesi Sosyal Bilimler Enstitüsü Dergisi, 20(3), 277-296. https://doi.org/10.12984/egeefd.526276

MEB. (2013). Okul öncesi eğitim programı. MEB. https://doi.org/10.14527/9786053183563b2.035 
NEILL, A. S. (2000).Öözgürlük okulu (1. baskı). (N. Şarman, Çev.) Payel Yayınları.

Oğuz, V. (2019). Okul öncesi dönemdeki çocukların korkuları ve nedenleri. Internatıonal Journal of Human Sciences, 16(1), 192-204. https://doi.org/10.14687/jhs.v16i1.5657

Öveç, Ö. (2012). Okul öncesi eğitim alan 6 yaş çocuklarının bazı duyguları (sevgi, korku, mutluluk, üzüntü) resmetmelerinin incelenmesi. Yüksek Lisans Tezi. 12 3, 2019 tarihinde https://tez.yok.gov.tr/UlusalTezMerkezi/TezGoster?key=rcbWnuqW6HxCZ_98ARapgqCGka 9OsrPoQfGZq910ir--yVvhzNigs93Co5PqoEnxı https://doi.org/10.30900/kafkasegt.571869

Özcan, Ö., Kılıç, B. G., ve Aysev, A. (2006). Okul korkusu yakınması olan çocukların ana babalarında ruhsal bozukluklar. Türk psikiyatri dergisi, 17(3), 173-180.

Özdemir, M. (2010). Nitel veri analizi: sosyal bilimlerde yöntembilim sorunsalı üzerine bir çalışma. Eskişehir Osmangazi Üniversitesi Sosyal Bilimler Dergisi, 11(1), 323-343. https://doi.org/10.17494/ogusbd.281805

Öztürk, M., ve Giren, S. (2016). Okul öncesi dönemdeki çocuklar için hazırlanan hikâye kitaplarındaki korku ve şiddet öğelerinin incelenmesi. Uluslararası Türkçe Edebiyat Kültür Eğitim (TEKE) Dergisi, 5(4). https://doi.org/10.7884/teke.585

Öztürk, Ş. (2006). Televizyonda şiddet içerikli yayınlar karşısında çocuğun durumu, II. Uluslararası Çocuk ve İletişim Kongresi, 3-22.

Piaget, J., ve Inhelder, B. (2019). Çocuk psikolojisi (3. bask1). (O. Türkay, Çev.) Pinhan Yayıncılık.

Sapsağlam, Ö. (2017). Okul öncesi dönem çocuklarının değer algılarının çizdikleri resimler ve sözlü anlatımlarına göre incelenmesi: sorumluluk değeri örneği. Ĕgitim ve Bilim Dergisi, 42(189), 287-303. https://doi.org/10.19171/uuefd.11636

Sargın, N. (2012). Çocuklarda ruh să̆llğı (2. bask1). Eğitim Kitapevi.

Savaş, İ. (2014). Çocuk resmi ve bilinçaltı. Yüksek Lisans Tezi. 10 19, 2019 tarihinde http://arelarsiv.arel.edu.tr/xmlui/handle/20.500.12294/66

Scheer S, Mares, M. L., Bartsch, A., ve Goetz, M. (bar). Parents, television, and children's emotional expressions: a cross-cultural multilevel model. Journal of Cross-Cultural Psychology, 50(1), 22-46. https://doi.org/10.1177/0022022118806585

Seggie, F. N., ve Bayyurt, Y. (2017). Nitel araştırma (2. baskı). Anı Yayıncılık.

Senemoğlu, N. (1994). Okul öncesi eğitim programı hangi yeterlilikleri kazandırmalıdır? Hacettepe Üniversitesi Eğitim Fakültesi Dergisi, 10, 21-30. https://doi.org/10.24315/trkefd.366706

Tahiroğlu, A. T., Çelik , G. G., Kayhan, B., ve Ayşe, A. (2010). Medyanın çocuk ve gençler üzerine olumsuz etkileri; şiddet eğilimi ve internet bağımlığı. New/Yeni Symposium Journal , 48(1), 21 31 .

TDK. (2019, 10 19). Korku nedir? Türk Dil Kurumu: https://sozluk.gov.tr/?kelime=KORKU a

Türkarslan, N. (2007). Boşanmanın çocuklar üzerine olumsuz etkileri ve bunlarla başetme yolları. Sosyal Politika Çalışmaları Dergisi, 11(11), 99-108.

Uyan, T. T., Bahçeci, B., ve Hocaoğlu, Ç. (2018). Gök gürültüsü korkusu 'brontophobia': bir olgu sunumu. Düzce Üniversitesi Sağllk Bilimleri Enstitüsü Dergisi, 8(3), 151-153. https://doi.org/10.30569/adiyamansaglik.338774

Ünal, N., ve Durualp, E. (2012). Televizyonun okul öncesi çocuklar üzerindeki etkisi. Çankırı Karetekin Üniversitesi Sosyal Bilimler Dergisi, 3(2), 93-104. 
Yaşar, V., ve Yaşar, S. (2010). Okul çağındaki çocuklarda görülen okul korkusu. Bilim ve Aklın Aydılnlığında Eğitim, 16(24), 126-127.

Yavuzer, H. (2015). Çocuk psikolojisi (38. bask1). İstanbul: Remzi Kitapevi.

Yavuzer, H. (2017). Resimleriyle çocuk- resimleriyle çocuğu tanıma (21. bask1). İstanbul: Remzi kitapevi.

Yüksekusta, S. Y., ve Şahin, F. T. (2016). Çocuk resimlerinde spor. International Journal of Sport Culture and Science, 4(1), 214-227.

Yüksel, M. Y., Canel, N., Mutlu, N., Yılmaz, S., ve Çap, E. (2015). Okul öncesi çağdaki çocukların "iyi" ve " kötü" kavram algılarının resim analizi yöntemiyle incelenmesi. Değerler Eğitimi Dergisi, 13(29),71-303. https://doi.org/10.34234/ded.402313 